\title{
Towards a concept of Communicative Competence in Health: a qualitative study in medical residents ${ }^{1}$
}

\author{
Rodolfo A Cabrales*
}

First publication online: 30 June 2015

\begin{abstract}
Despite the wealth of literature surrounding the importance of effective communication in the clinical practice, there is a dearth of consensus in the literature on what communicative competence in health $(\mathrm{CCH})$ is, and the practices of meaningful health communication. Seventeen residents (17) were invited to share their thoughts on the concept of communicative competence in health and on difficulties they encounter during their clinical practice related with communication. The aim of this study was to gain a better understanding of $\mathrm{CCH}$ with emphasis on the implications in the medical curriculum, teaching, learning and assessment. Three focus group discussions were conducted with the clinical supervisor. The results were audio-taped, transcribed verbatim and analyzed using principles from grounded theory for qualitative data analysis. ${ }^{2}$ The 135 open codes and defined axial codes were discussed and a number of conceptual frameworks were utilized to disentangle the concept of $\mathrm{CCH}$. The focus group themes related to the concept of communication in health, its importance and difficulties, the role of the physician and health personnel. The participants felt their own training did not prepare them to establish effective communication with patients and relatives. Some barriers include lack of time and lack of institutional priority given to communication issues. The techniques originating from grounded theory permitted to define a broader concept of $\mathrm{CCH}$ with the following three specific scopes: biological perspective (objective world), social (social world) and subjective world (expressive-aesthetic). This new concept of CCH is central to understanding how the health communication process occurs, where a myriad of individual (physician, patient, staff, relatives), organizational and societal interrelated factors influence health decisions and practice. These components need
\end{abstract}

* Dr. Rodolfo A Cabrales (rocabral@utp.edu.co) is a faculty member at the Department of Clinical Sciences in Health Sciences Faculty at Universidad Tecnológica de Pereira, Colombia.

${ }^{1}$ I wish to thank all medical doctors who participated in focus groups. In addition, I acknowledge the assistance of Department of Clinical Epidemiology, Universidad Tecnológica de Pereira, which supported us in setting up the focus groups, peer discussion and analysis phases. The author reports no conflict of interest.

${ }^{2}$ Anselm Strauss and Juliet Corbin, Basics of Qualitative Research: Techniques and Procedures for Developing Grounded Theory (California/ London: Sage Publications, 2008). 
to be addressed by medicine schools, health institutions and other stakeholders in the planning and designing a new model of curricula.

Keywords: Health communication; communicative competence; medical competences; medical communication skill; medical education.

\section{Introduction}

A healthcare culture of rationed resources and targets that focus on outputs can compromise professionals' ability to respond to the needs of individual people. ${ }^{3}$ Complaints about professional communication focus on the loss of humanity when patients ask for help and feel they are treated as part of a system and not as individuals. ${ }^{4}$

It is universally accepted that communication, with emphasis on the experience of the person, is essential for all student health care professionals. ${ }^{5}$ The recent consensus statement on the content of medical students' communication curriculum places respect for others at the centre of the communication curriculum wheel. ${ }^{6}$ It is recognized, at undergraduate level, that the competences included in this wheel are higher order skills., ${ }^{7,8}$

However, the majority medical curricula in Colombia do not include formal training in communication skills and some of them are best acquired in a clinical context, during all stages of training. This learning tends to

${ }^{3}$ Paul Bate, Peter Mendel, and Robert Glenn, Organising for quality: The improvement journey of leading hospitals in Europe and the United States (Oxford: The Nuffield Trust, Radcliffe Publishing, 2008).

${ }^{4}$ Elizabeth Anderson, Jenny Ford, and Lucy Thorpe, «Learning to listen: Improving students' communication with disabled people,» Medical Teacher 33, $\mathrm{n}^{\circ} 1$ (2011): 44-52.

${ }^{5}$ Universities UK, «Statement of guiding principles relating to the commissioning and provision of communication skills in preregistration and undergraduate education for healthcare professionals Universities UK,» United Kingdom, 2003.

${ }^{6}$ Paul Kinnersley and John Spencer, «Communication skills teaching comes of age,» Med Educ 42 (2008): 1052-1053.

7 Adrian Hastings, Robert McKinley, and Robin Fraser, «Strengths and weaknesses in the consultation skills of senior medical students: Identification, enhancement and curricular change,» Med Educ 40, n 5 (2006): 437-443.

${ }^{8}$ Simon Watmough, Anne Garden, and David Taylor, «Does a new integrated PBL curriculum with specific communication skills classes produce Pre Registration House Officers (PRHOs) with improved communication skills?,» Medical Teacher, 28, nº 3 (2006): 264-269. 
decline with time unless regularly recalled and practised..$^{9,10,11,12}$ Most medical schools and hospitals find it still difficult to implement clinically-based, longitudinal communication skills training programs.

Coherent models for teaching communication skills in clinical practice have been developed and diffused in other countries. ${ }^{13}$ However, extending communication training coherently into clerkship and residency and ensuring that clinical faculty supports and teaches communication skills beyond the formal communication course remains challenging. ${ }^{14,15,16}$

It is possible that part of the problem lies in a weak understanding about what communicative competence in health is? As pointed out by Cook there is an urgent need for clarification research to advance the science of medical education. ${ }^{17}$ This view is supported by de Haes who stated that the evidence on medical communication is underdeveloped. ${ }^{18}$ Conceptual models in this area are still lacking. The aim of this study was to gain a better understanding of factors affecting communication process in health setting as a first phase for developing a broader category called $\mathrm{CCH}$.

Qualitative research helps us to understand why and how communication occurs in the physician-patient relationship and offer rich resource for communication skills trainers and curriculum developers. The focus group

9 Joseph Flaherty, «Education and evaluation of interpersonal skills,» in The interpersonal dimension in medical education, ed. Agnes Rezler and Joseph Flaherty (New York: Springer Verlag, 1985), 101-146.

${ }^{10}$ Knut Aspegren, «BEME Guide No. 2: Teaching and learning communication skills in medicine - A review with quality grading of articles,» Medical Teacher 21 (1999): 563-570.

${ }_{11}$ Association of American Medical Colleges, «Report 3. Contemporary issues in medicine: Communication in medicine,» Washington, DC., 1999.

${ }_{12}$ Charlotte Rees and Paul Garrud, «Identifying undergraduate medical students' attitudes towards communication skills learning: a pilot study,» Medical Teacher 23, $\mathrm{n}^{\circ} 4$ (2001): 400-406.

13 Jonathan Silverman, Suzanne Kurtz, and Juliet Draper, Skills for communicating with patients, 2nd ed. (New York: Radcliffe Publishing Ltd., 2013).

${ }^{14}$ Suzanne Kurtz et al., «Marrying content and process in clinical method teaching: Enhancing the Calgary-Cambridge guides,» Acad Med 78 (2003): 802-809.

15 Katrien Bombeke et al., «Patient-centredness from education to practice: The 'lived' impact of communication skills training,» Medical Teacher 34 (2012): e338-e348.

${ }^{16}$ Lavjay Butani et al., «Attributes of residents as teachers and role models - A mixed methods study of stakeholders,» Medical Teacher 35 (2013): e1052-e1059.

17 David Cook, Georges Bordage, and Henk Schmidt, «Description, justification and clarification: a framework for classifying the purposes of research in medical education,» Med Educ 42 (2008): 128-133.

${ }^{18}$ Hanneke De Haes and Jozien Bensing, «Endpoints in medical communication research, proposing a framework of functions and outcomes,» Patient Educ Couns. 74 (2009): 287-94. 
method was chosen because it is an appropriate method to elicit a wide range of ideas and opinions on a well-defined topic.

\section{Methods}

\section{Participants}

The study was conducted under a period of six months in 2010-2011. Seventeen (17) first (9) and second year (8) residents of Medicine Postgraduate Program in Health Science Faculty in the Universidad Tecnológica de Pereira were recruited. They worked on the wards of Internal Medicine (7), Psychiatry (7) and Critical Care Units (3) in the Hospital Universitario San Jorge-PereiraColombia. In their undergraduate medical curriculum, this group had had diverse experiences of communicative competence development, from formal courses to ward's communication learning practices with patients and teachers.

The study was approved by Universidad Tecnológica de Pereira Research Ethics Committee. All participants provided written informed consent prior to participation. To achieve the transparency, the author kept the participants informed of the study progress throughout the whole process.

A focus group with a number of clinical residents evaluated their experiences of interacting with patients, relatives and health personnel, their own communication abilities and difficulties encountered during the process of the communicative competence development. The data saturation point determined the number of focal groups.

\section{Interventions}

\section{Table 1}

Focus group discussion guide

1. What qualities do you think make a physician a good "communicator"?

2. What behaviours do you observe that affect the physician-patient communication process?

3. If you could imagine a training program to teach communication skills:

a. What topics do you think should be taught?

b. What methods do you think should be used? 
A discussion guide was developed with input from a group of clinicians experienced in communication and researchers experienced in focus group methodology (Table 1).

\section{Objective}

The objective was to determine the external and internal factors affecting the health communication process and how communication skills can be taught, learned and practised.

We hypothesized that having a more comprehensive concept of communication in health contexts would facilitate a more accurate approach on complexity and diversity of communication process between physicians and patients.

\section{Analysis}

Focus group sessions lasted 120 minutes. Transcribed data from the focus groups, and free text comments from memos were typed into Microsoft Word and analysed. All personal identifiers were removed in order to maintain anonymity and confidentiality. Themes were coded and sorted using the principles of Grounded Theory..$^{19}$ New insights about the concept of $\mathrm{CCH}$ were written down in memos. The first stage (open coding) involved the identification of broad themes in which the data were taken apart and examined for differences and similarities. These first-level categories were then broken down into further subcategories (stage two, axial coding). The emerging themes were ranked in order of prominence and summarised.

The interpretative phase was based on the data triangulation process, which put together the information of the three parties involved..$^{20}$

- Informants' input: information directly obtained from the participants.

- Information gathered: the theoretical analysis made by the researcher through all the phases of the process.

19 Barney G. Glaser, Basics of Grounded Theory Analysis: Emergence Vs. Forcing (Mill Valley, CA: Sociology Press, 1992).

${ }^{20}$ Don Des Jarlais, Cynthia Lyles, and Nicole Crepaz, «Improving the reporting Quality of Nonrandomized Evaluations of Behavioral and Public Health Interventions: The Trend Statement,» American Journal of Public Health 94 (2004): 361-366. 
- Researcher's information: the researcher's position, based on his/her personal remarks, memoranda, field journals and complementary personal documents.

Given the qualitative nature of the data, findings are reported in broad terms (e.g. most, many, several, some and few).

\section{Results}

Three focus groups were conducted. Participants included 17 physicians with the average age 32 years (for the sample of each group, see Table 2). 135 open codes were created. The overall analysis shows that health communication is a critical part of health practice, but there was a dearth of consensus among the participants on what $\mathrm{CCH}$ is, and the practices of ideal health communication. Two main themes emerged from the analysed data: Communication in Clinical practice; and Communication in the context of Medical Education. The results are presented using these themes with their categories and sub-categories (Table 3). Quotations are included in the results to illustrate how the interpretation is grounded in the data. Interviews were conducted in Spanish, translated in English by a professional translator; and for each quotation, the original transcripted text is provided, in italics, between parenthesis, for the sake of transparency.

\section{Table 2}

Description of the focus groups

\begin{tabular}{|l|c|c|c|c|}
\hline \multicolumn{1}{|c|}{ Main indication(s) } & Group 1 & Group 2 & Group 3 & Total \\
\hline Number & 6 & 6 & 5 & 17 \\
\hline Year of residence $\left(1^{\circ}: 2^{\circ}\right)$ & $3: 3$ & $3: 3$ & $3: 2$ & 17 \\
\hline Gender (male:female) & $5: 1$ & $5: 1$ & $5: 0$ & 17 \\
\hline Age $(\bar{X})$ & 30.8 & 31.3 & 33.8 & $\mathbf{3 2}$ \\
\hline
\end{tabular}




\section{Communication in the Clinical Practice}

\subsection{Actors}

\subsubsection{The physician must be a physician and look like one}

Some participants put emphasis on the physical appearance, the need to use the white robe as a way to fit in with the image the patient has regarding the physician. In general, it is the social concept about the physician, his/her physical aspect and his/her attire, among others, wearing the white robe as a symbol of neatness and status.

... and I think the appearance matters, not in the sense of boasting of how neat my robe is, or the fact that I am wearing a tie or I am dressed up, but it must be respectful as to how this appearance projects before their patient; at least well dressed, not trying to be superior, as we are really equals, but at least the basic rules we would also expect from the other person. (...y creo que la apariencia importa no en cuanto a ostentar de que tengo la bata pulcra, de que tengo corbata, adornado, pero si debe tener un respeto en cuanto a cómo se va a proyectar ante su paciente, por lo menos arreglado, digamos, cierta presentación, no tratando de ser superior al otro, porque en realidad somos iguales pero si por lo menos las normas básicas que uno esperaría también de la otra persona que viene a hablar..). ${ }^{21}$

The patient also has to trust that in the human being who is wearing the white robe, a man/woman who is close, can help them.

Besides the issue of the clothing, I am not the right person to say it, but I believe the habit makes the man; if one is a physician, we have to feel as such, and the robe gives us not the status of a physician, but the status that I can help you. (Aparte, lo de la vestimenta, no soy el más correcto para eso, pero creo que obviamente el hábito hace al monje, si uno es médico, tiene que sentirse como un médico y la bata le da a uno no el estatus de ser médico sino el estatus de que puedo ayudarlo a usted.). ${ }^{22}$

In other words, the presence of the white robe is necessary in order for the communication process between the doctor and the patient to start.

${ }^{21}$ Participant 1, codenamed C69ABP13 for confidentiality reasons. Group 1. Date and place of interview: Clinical Sciences Department - Room 3,13 August 2012.

${ }^{22}$ Participant 2, codenamed C81DEP17 for confidentiality reasons. Group 2. Date and place of interview: Clinical Sciences Department - Room 3, 22 February 2013. 
Table 3

Analysis process and resulting themes

\begin{tabular}{|c|c|c|}
\hline Subcategories & Categories & Themes \\
\hline Physician & \multirow{3}{*}{ Actors } & \multirow{8}{*}{$\begin{array}{l}\text { Communication in } \\
\text { Clinical practice }\end{array}$} \\
\hline Patient & & \\
\hline Family & & \\
\hline Health System & \multirow{3}{*}{$\begin{array}{l}\text { Environment for } \\
\text { health communication }\end{array}$} & \\
\hline Time for medical encounters & & \\
\hline $\begin{array}{l}\text { Tools for an effective communication } \\
\text { in the clinical practice }\end{array}$ & & \\
\hline Context & \multirow{2}{*}{$\begin{array}{l}\text { Tools for an effective } \\
\text { communication in the } \\
\text { clinical practice }\end{array}$} & \\
\hline Emphatic Listening & & \\
\hline Bidirectionality & \multirow{2}{*}{$\begin{array}{l}\text { Learning and Teaching } \\
\text { communication skills }\end{array}$} & \multirow{2}{*}{$\begin{array}{l}\text { Communication and } \\
\text { Medical Education }\end{array}$} \\
\hline Comprehensive Training & & \\
\hline
\end{tabular}

\subsubsection{The patient}

Many participants think that the kind of patient determines the kind of communication. The vital cycle (childhood, adulthood and old age), the type of disease, its progress and prognosis, the patient's perception about feeling ill and the functional disability. These factors determine the success of the communicative act and its effectiveness.

... And most important thing that I think the doctor should have is an ability to take the patient's perspective or put oneself into the shoes of the patient, i.e. imagine that if I were in his place, with the same condition, how it would be, what would happen ... I think these are two fundamental things that a doctor must have in order that there is good communication between the physician and the patient. (...y lo más importante que me parece el médico debe tener una capacidad de ponerse en el lugar del paciente o ponerse en los zapatos del paciente, o sea, detectar si yo estuviera en el lugar de él, con esa misma condición, como sería todo, como pasaría... me parece que son dos cosas fundamentales que debe tener un médico para que haya una buena comunicación entre el médico y el paciente.). ${ }^{23}$

${ }^{23}$ Participant 3, codenamed C3AMP1 for confidentiality reasons. Group 1. Date and place of interview: Clinical Sciences Department - Room 3, 31 August 2012. 


\subsubsection{The family}

Family nowadays adds to the bilateral relationship between the physician and the patient. During the interventions, the importance of the family as part of comprehensive health care and important source of gratification for the patient was highlighted, without leaving concerns and difficulties behind.

The second point I should mention is the family, as an important nucleus in the physician-patient relationship. APA [American Psychiatric Association] guidelines or recommendations suggest (ideally) the participation of the family during reanimation, but this is not done in our cultural environment not because it is difficult to train physicians, but it is very difficult to train the assistant staff. (El segundo punto frente al que tendría que hacer mención es la familia, como núcleo importante dentro de la relación médico paciente, las guías o recomendaciones de la APA [Asociación Americana de Psiquiatría] sugieren la participación de la familia en los instantes de reanimación que sería lo ideal, que en nuestro medio culturalmente no lo hacemos, por las dificultades que tenemos en cuanto al entrenamiento no del personal médico sino de los otros que asisten.). ${ }^{24}$

Many participants agreed that communication with the family is different from communication with the patient, as it requires special conditions and entails different expectations.

time one communicates with the patient or the family, there has to be a comfortable environment, with the patient and his/her family sitting, comfortable, so that one can look at them in their eyes, face to face. First, it is necessary to find out what the patient or his family knows about the disease, what have they heard about it, what do they know about it. (Siempre que uno va a comunicarse con el paciente, con la familia, primero tiene que haber un ambiente cómodo, que ojala el paciente o la familia, todos estén sentados, que todos se sienten cómodos, que uno pueda mirarlos a los ojos, frente a frente, primero intentar averiguar que es lo que el paciente o que es lo que la familia sabe de la enfermedad, qué es lo que le han comentado, cuál es el conocimiento que tienen.). ${ }^{25}$

${ }^{24}$ Participant 4, codenamed C84aChP18 for confidentiality reasons. Group 2. Date and place of interview: Clinical Sciences Department - Room 3, 22 February 2013.

${ }^{25}$ Participant 5, codenamed C27WBP4 for confidentiality reasons. Group 1. Date and place of interview: Clinical Sciences Department - Room 3, 31 August 2012. 


\subsection{Environment for health communication}

External elements that affect the communication process during the physician-patient meeting are included in this category.

\subsubsection{Health care system. An obstructive system.}

Consensus was reached about the health system as a barrier to promote effective health communication. The quality of health services was frequently thought to be poor and therefore more detrimental to patients' recovery than helpful. The "health system" was most often blamed for not allowing for protracted conversations with patients. Prolonged waits for specialized consultations, medications and surgeries in most cases are contributing factors that affect physician-patient relationship.

....as long as there are no changes in the entire health system and the entire health structure we are creating, it is like ploughing on arid soil, because, as long as the doctor is limited by time, by a number of bureaucratic obstacles, by a business health model that hinders him/her from prescribing medicines, from requesting for the tests he/she deems pertinent, he/she will not be able to establish empathy or a proper physician-patient relationship. (...mientras no haya un cambio, en toda la estructura de salud y en todo el sistema de salud que estamos creando, esto es arar en terreno árido porque mientras el médico esté limitado. por un tiempo, por una cantidad de trabas burocráticas limitado por un modelo de negocio en salud que le impida formular medicamentos, que le impida pedir los exámenes que considere que su criterio definiera, no va, no va a establecer una empatía o no va a establecer una adecuada relación médico-paciente. . ${ }^{26}$

Unlike the kind of physician that the health system provides, many participants yearn for the physician that was around a few decades ago (the small town doctor), gifted with good communication skills and the ability to listen, among other qualities. The small town physician rises as a model that society confronts to the current, more "scientific" physician, with less communication skills.

...one sticks to a model and we see, as a friend here said, that it is the small town physician model, who contextualizes the patient, considers several aspects, goes deeper, has a good relationship with the family... it is a very

${ }^{26}$ Participant 6, codenamed C18IPP3 for confidentiality reasons. Group 1. Date and place of interview: Clinical Sciences Department - Room 3, 31 August 2012. 
good model. (...uno se rige a un modelo y vemos como menciona el compañero, que es el modelo del médico del pueblo, que es un modelo que contextualiza el paciente, tiene en cuenta varias cosas, profundiza, tiene buena relación con los familiares, es un modelo muy bueno.). ${ }^{27}$

The small town physician you mentioned (whom we knew for 8 years), enters the patient's world, gets to know his/her family, the person who takes care of the elderly, or the child, or if the mother and father of the child in question are not there and there is a nanny, etc. He/she establishes a series of different communication acts for different people. (El médico del pueblo que decían ustedes aquí, durante 8 años conocimos, entonces es entrar en ese ámbito de los pacientes, conocer su familia, conocer quien cuida el viejito o quien cuida este niño, o si la mamá y el papá de este niño no están, está la empleada y establecer una serie de comunicaciones diferentes para con diferentes tipos de personajes.). ${ }^{28}$

\subsubsection{Time for medical encounters}

Most of the participants were confronted with barriers such as time pressure, workload and service schedules that impede an emphatic communication. In addition, many participants stressed the importance of a "listening physician" as a means to ensure a more accurate clinical diagnosis.

I long for the physician who took the time to sit and talk with his/her patient, and gets to know him/her, because now one imagines that type of situation: you move around while the patient goes to the examination table, takes his/her clothes off, you examine him/her and then write the report and prescription on the computer; 15 minutes are gone. (Me da mucha nostalgia del médico que antes podía tomarse el tiempo para sentarse y hablar con su paciente y conocerlo, porque ahora usted se ve abocado a una situación de esas y usted voltea a mirar y mientras la paciente se sube, le quita la ropa, la examina y se hace la nota en el computador, la fórmula y todo esto, ya se le fueron los $15 \mathrm{~min}$.). ${ }^{29}$

27 Participant 7, codenamed C74CFP14 for confidentiality reasons. Group 2. Date and place of interview: Clinical Sciences Department - Room 3, 22 February 2013.

${ }^{28}$ Participant 8, codenamed C106aAGP26 for confidentiality reasons. Group 3. Date and place of interview: Clinical Sciences Department - Room 3, 30 August 2013.

${ }^{29}$ Participant 9, codenamed C91MVP20 for confidentiality reasons. Group 2. Date and place of interview: Clinical Sciences Department - Room 3, 22 February 2013. 
Another frequently mentioned aspect in the communication competence was time efficiency without putting aside either the patients or the doctor's agenda.

[We want] a system where the physician can have a paramount role and can sit and talk with his/her patient. ([Queremos] un sistema en el que nuevamente el médico pueda tener un papel estelar y sentarse a conversar con su paciente.). ${ }^{30}$

1.3. Tools for an effective communication in the clinical practice.

The participants describe a wide range of anticipated and expected outcomes covering many dimensions of health and psychosocial issues that influence the success in a medical-patient relationship in order to achieve an effective communication.

\subsubsection{The importance of context.}

Some participants said that meaningful communication mostly depends on the physician's attitude, the clinical environment and the time available for the interview.

... and they go straight to the point, with a focused clinical interview; we understand that time limit is a factor, as well as administrative matters; the key is not to interrupt the patient, being empathetic, so that the patient trusts us; leave him/her talk freely about his/her complains and the reasons for the appointment. (...y empiezan a apuntar ya en relación y hacen un interrogatorio completamente enfocado y entiende uno que es por la limitantes del tiempo y la parte administrativa y todas esas cosas, pero lo clave y lo fundamental es que uno deja al paciente al inicio, no interrumpirlo para lograr una empatía y que él confie en uno, dejarlo hablar libremente para saber cuáles son sus quejas y lo que lo está motivando en ese momento a venir a la consulta.). ${ }^{31}$

This communicative competence concept comprises several variables, such as time, the depth of the interview, and the clinical environment, among others.

${ }^{30}$ Participant 9, codenamed C57MVP11. Focus Group 2, 22 February 2013.

${ }^{31}$ Participant 10, codenamed C49JJP8 for confidentiality reasons. Group 2. Date and place of interview: Clinical Sciences Department - Room 3, 22 February 2013 
...the contexts where physicians work should be taken into account; that is, clinical practice. Communication is different if it takes place in the private practice, as it is in the ER or in the ward, or in the ICU. There are situations in the different services that allow us more time to obtain the information required. (...debería tenerse en cuenta los contextos en donde nos movemos los médicos, o sea, las clínicas. La comunicación es diferente en la consulta externa, como es diferente en urgencias, como es diferente en las sala como será diferente en una unidad de cuidado intensivo. Hay situaciones en los diferentes servicios que le permiten a uno tener más tiempo para obtener la información que se requiere.). ${ }^{32}$

Another aspect is that we have to categorise communication according to the type of patient since communicating with the patient who goes to the clinical practice is different from communicating with the one who is in the hospital, they are in different environments. Then, sometimes I see that physicians that are going to work in private practices are very well trained, which is different in the case of hospitals, because it is not easy to differentiate what the patient needs and what he/she wants. (Otra cosa es que también tenemos que dividir de pronto la comunicación con el paciente que asiste a consulta que es muy diferente a la comunicación que uno tiene con el paciente clínico, con el paciente hospitalizado en otro ambiente diferente, entonces a veces yo veo que lo que forman es muy bien es al médico que va a hacer consulta pero qué difícil es lo que necesita el paciente lo que quiere el paciente y lo que yo logro ver en el ambiente hospitalario.). ${ }^{33}$

\subsubsection{The physician as empathetic listener}

Empathic listening was also directly linked to positive therapeutic effects. Some argue that when the doctor does not listen to the patient's concerns it can lead the patient to mistrust their own judgement, intuition and the signals their bodies are transmitting.

... and last, but not least, what I think is that the most important aspect is in the physician-patient relationship that you mentioned earlier: the empathetic listener; empathy is the ability to bring to my actions, to my conversation and to my language the feeling and motivation for the patient to trust me. (...y lo último, que a mí me parece que es lo más importante para la relación medico paciente, lo dijeron ustedes mismos: el oyente empático,

32 Participant 8, codenamed C110AGP27. Focus Group 3, 30 August 2013.

${ }^{33}$ Participant 11, codenamed C43CGP7 for confidentiality reasons. Group 1. Date and place of interview: Clinical Sciences Department - Room 3, 31 August 2012. 
empatía es la capacidad que tengo de imprimirle a mis acciones, a mi dialogo y a mi lenguaje ese sentimiento, esa motivación para que el paciente llegue a mí.). ${ }^{34}$

Unlike "passive listening", many respondents agreed on presenting a type of physician focused on "active listening" or "attentive listening", which includes, among other actions, waiting prudently, facilitating the patient's reply, catching his/her non-verbal language and stimulating physical contact. In short, making the patient see in the physician all the qualities that make him/her feel confident and express him/herself without any fear.

...in the first 30 seconds, you have to begin to establish rapport or trust with our patient; if we achieve from the very first seconds to establish this trust, he will start talking about his/her life. (...en los primeros 30 segundos uno tiene que empezar a establecer lo que nosotros llamamos un rapport o una confianza en nuestro paciente si logramos desde los primeros segundos entablar esa confianza, el va a empezar a soltar toda su vida.). ${ }^{35}$

... and finally, body language is very important, as I said; I always make physical contact with my patients, as I think that, more than just words, it is preferable to hold his/her hand, shake it [... "step down", become an equal and emphasize with their position. (...y por último, existe un lenguaje corporal bien importante, que lo decía ahora y me parece espectacular, yo siempre toco los pacientes, me parece más importante que uno decirle a los pacientes muchas cosas, muchas palabras, tocarlo, darle la mano, saludar el paciente de mano [...] bajarse, igualarse y ponerse en la posición de cada persona.). ${ }^{36}$

There is the hermeneutics: what are you saying to me with your face, with the volume or your voice, with the prosody; also, I have to pay attention to how I say things and what I am saying, and what this means to you. (Estoy teniendo en cuenta que ahí ya entra la hermenéutica, usted qué me está queriendo decir con sus caras, qué me está queriendo decir con el volumen de su voz, con toda la prosodia y poner mucha atención en cómo estoy diciendo las cosas y qué es lo que estoy diciendo, y qué significa para usted lo que yo estoy diciendo.). ${ }^{37}$

${ }^{34}$ Participant 12, codenamed C97JCP23 for confidentiality reasons. Group 2. Date and place of interview: Clinical Sciences Department - Room 3, 22 February 2013.

${ }_{35}$ Participant 13, codenamed C7MNP1 for confidentiality reasons. Group 1. Date and place of interview: Clinical Sciences Department - Room 3, 31 August 2012.

${ }_{36}$ Participant 8, codenamed C109AGP27. Focus Group 3, 30 August 2013.

37 Participant 14, codenamed C118APP33 for confidentiality reasons. Group 3. Date and place of interview: Clinical Sciences Department - Room 3, 30 August 2013. 


\section{Communication and Medical Education}

\subsection{Learning and Teaching communication skills. Towards a concept of $\mathrm{CCH}$.}

The focus group explored participant's positive and negative attitudes to communication skills development during medical education. Some of the participants indicated to be shocked by the huge disparities between the training ground of communication learning and real practice. Apparently, neither communication skills learning nor clerkship education had provided them with the tools to build comprehensive patient-centred communication in real practice. Some participants, however, recycled these "basic materials" and used them to create their personal models of being patientcentred.

I think we should have stronger grounds to conduct the clinical interview, such as knowing how to obtain the information and how to give information, because Faculty teaches us to be a doctor, but how to communicate and how to be a gentleman one learns at home, it starts with good manners. (Creo que uno debería tener unas bases más fuertes para poder dirigir el interrogatorio, saber extraer la información, saber dar noticias, porque a uno en la facultad le enseñan a ser doctor, pero la comunicación y el ser señor viene desde la casa, desde los modales.). ${ }^{38}$

For some participants, their professors are not good models of meaningful communication, neither in the classroom nor in the clinical practice sites.

At least in my faculty, we were allocated a number of patients, and we received a theory of clinical interview and a theory of the clinical record, but the teachers leave and one has to get in touch with the patient, interview $\mathrm{him} / \mathrm{her}$, by oneself. (Por lo menos en mi facultad a nosotros nos distribuían una serie de pacientes, a usted le dan una teoría del interrogatorio y una teoría de la historia clínica pero él se va y usted solo tiene que llegar a tener contacto con el paciente, interrogarlo.). ${ }^{39}$

Errors in the preponderance of the result over the process are described. It is more important to obtain a trustworthy diagnosis than the communication act that was part of the process.

No, and there was no one with me when I was interviewing the patient, they only looked at the results; when the specialist or professor asks about the

${ }_{38}$ Participant 11, codenamed C46CGP8. Focus Group 1, 31 August 2012.

39 Participant 11, codenamed C38CGP6. Focus Group 1, 31 August 2012. 
patient, you have a number of signs and symptoms, but [the professors] did not know how you draw them, how did you obtain the information. (No, ni alguien estaba pendiente de mi cuando yo estaba haciendo el interrogatorio con el paciente, solo veían los resultados, cuando pasa el especialista o el profesor a decir qué tiene el paciente, usted tiene una serie de signos y síntomas pero [los profesores] no supieron cómo los adquirió, como los extrajo, cómo obtuvo la información.). ${ }^{40}$

During the years of study of the clinical speciality, the communication model learnt during the pre-graduate years seems to prevail.

I have never seen the ICU head, from here or from the hospital where I am doing my internship, to go out and talk to the patients' families. They generally leave that unpleasant role to us, medical students. A system or time period to receive the patients' families is not established either. (Yo nunca he visto al jefe de la unidad de cuidado intensivo ni de acá ni del hospital donde me estoy entrenando salir y hablar con las familias de los pacientes. Generalmente ese papel tan maluco nos lo dejan a nosotros los residentes. Ni tampoco está estatuido un sistema o un espacio en el tiempo en el que se pueda atender a las familias de los pacientes.). ${ }^{41}$

Besides positive attitudes to patient-centredness, responsibility towards "own" patients and creativity were found to be two important drivers stimulating this ever-developing process.

This concept of communication in health is better understood if we consider both the doctor and the patient as subjects, and not as a subject and an object. Indeed, the concept of communication competence appeared to be shifted from a list of attitudes and skills to the wishes of individual, real patients themselves within their unique context.

Simply try to find this relativity and balance when giving health care to the patient; but that is something one has to learn, understand and it does not have to be so standardised. (Simplemente tratar de buscar esa relatividady ese equilibrio en su atención al paciente, pero eso simplemente lo va aprendiendo uno, uno lo va a entender ynotiene que ser tan estandarizado.). ${ }^{42}$

40 Participant 11, codenamed C39CGP7. Focus Group 1, 31 August 2012.

${ }^{41}$ Participant 9, codenamed C58MVP11. Focus Group 2, 22 February 2013.

${ }^{42}$ Participant 15, codenamed C120SCP36 for confidentiality reasons. Group 3. Date and place of interview: Clinical Sciences Department - Room 3, 30 August 2013. 


\subsubsection{Bidirectionality}

Communication in health is acknowledged as a dynamic process, with its depth and multiple directions.

I think we have to consider it as a dynamic model; the relationship with the patient is not unidirectional, but bidirectional; also, it is necessary to consider the patient's family. (Me parece que hay que tenerlo como un modelo dinámico, la relación del paciente que tengo al frente no es algo unidireccional, es algo bidireccional, hay que tener en cuenta también a los familiares del paciente.). ${ }^{43}$

... because many times I cannot do a clinical interview, but a crisis interview; many times they [ER doctors] have to make an crisis interview because they need to obtain this information quickly, because they have to decide, they have to do it faster and make quick decisions; it goes from focused interview to clinical interview and it is during an interview that we have feedback. (...porque muchas veces no puedo hacer una entrevista y me toca hacer un interrogatorio, muchas veces ellos [los médicos de urgencias] se ven obligados a hacer un interrogatorio porque necesitan esa información rápido, porque tienen que decidir, porque les están exigiendo que tienen que ir más rápido que tienen que tomar decisiones rápido, va del nivel de interrogatorio al nivel de entrevista, y en la entrevista es donde vamos para ambos lados.). ${ }^{44}$

\subsubsection{Comprehensive training}

Linked to the communication process, several clinical residents mentioned the integral training at university as the process that guarantees the harmonic development of all the individual's dimensions: scientific, technological, ethical, cultural, social and humanistic, as expected from a good medicine professional.

We have forgotten the physician's integral context; I would like that, in the future, our training includes the arts; physicians playing music, talking about literature, or theatre, because that is going to make us more sensitive, allowing a much more acute diagnostic and therapeutic approach in favour of our patients. Also, this would allow us to improve our empathy and place

${ }^{43}$ Participant 16, codenamed C98AFP23 for confidentiality reasons. Group 3. Date and place of interview: Clinical Sciences Department - Room 3, 30 August 2013.

${ }^{44}$ Participant 16, codenamed C104AFP24. Focus Group 3, 30 August 2013. 
us in an adequate context. (Nos hemos olvidado del contexto integral del médico, me gustaría que a futuro hubiese en nuestra formación ese momento de hacer integralidad hacia las artes, me imaginaria a médicos haciendo música, hablando de literatura, hablando de teatro, porque eso nos va a llenar de sensibilidad y nos va a permitir una aproximación diagnóstica y terapéutica mucho más acertada para nuestros pacientes, y eso nos va a poder mejorar nuestros niveles de empatía y poder contextualizarnos de una manera adecuada.). ${ }^{45}$

... [he/she] must be a leading physician, who co-ordinates all the specialists; he/she has to go back to humanism and not to positivism, as we are currently witnessing. (...debe ser un médico líder que coordine a todos los especialistas y que sea como ese médico volver a la parte no del positivismo que estamos viendo actualmente sino del humanismo.). ${ }^{46}$

The data show that $\mathrm{CCH}$ may have different content within different medical specialities without it losing strength or value. The differences between specialities in time frames of physician-patient relationships, in acute versus chronic nature of illnesses, and kinds of treatments all seemed to require differentiations within the care rooted concept of "patientcentredness".

\section{Discussion}

This study was aimed at identifying the relationships framework in which the physician participates during his/her professional career. The results highlight the need to create empathetic and efficient communication with the patient and his/her family, not only expecting to decrease the possibility of complaints and suits in an increasingly discontinuous and fragmented model, but in the hope to restore the full dimension of medical practice.

First, this study highlights the increasing importance of family as an active and important participant of a successful medical intervention. In general, the type of communication of the patient reflects the communication model prevailing in his/her family. The physician has to be able to identify the type of family he/she is going to interact with. ${ }^{47}$ Thus, the families vary

45 Participant 4, codenamed C84ChP17. Focus Group 2, 22 February 2013.

${ }^{46}$ Participant 12, codenamed C95JCP22. Focus Group 2, 22 February 2013.

${ }^{47}$ Elayne Wittenberg-Lyles, Joy Goldsmith, and George Demiris, «The Impact of Family Communication Patterns on Hospice Family Caregivers,» Journal of Hospice and Palliative Nursing $14, \mathrm{n}^{\circ} 1$ (2012). 
regarding their communication habits between conformists and those that favour open communication. Identifying the kind of pattern prevailing in each family will allow the physician to plan his/her meetings and to obtain better results in the decision-making process and communication of bad news. ${ }^{48}$ This identification is crucial in specific subgroups. Like what was reported by other study in Critical Care Units, the subgroup of Critical Care medical students agreed on highlighting the importance of the family in communicating serious situations and on questioning how their professors taught those specific skills. ${ }^{49,50}$ On the other hand, unlike what Bascuñan reported ${ }^{51,52}$ about being threatened by the increasing autonomy and information the patients and their families have, many participants agreed that, in Colombia, the patient and his/her family still behave passively during the meeting with the physician.

Secondly, although the results of the present study agreed with those of Bascuñan on confirming the influence of the health system in the loss of autonomy of the physicians, they disagree about the role allocated to the patient. In the current Colombian health system, due to the fatigue of both patients and doctors, it is foreseeable that the initial contact between the physician and the patient is more a confrontational model than that of negotiation of interests. ${ }^{53}$

In general, changes in the physician-patient relationship and how they affect communication with the patient and his/her family, tend to be perceived as heteronomous and not autonomous. That is, as events determined by external factors (healthcare system, the patient, the time of the interview, among others) which directly modify the doctors' individual acts and their professional role. Although this autonomous component was not dealt with thoroughly in this study, its importance is acknowledged, as well as the need

${ }^{48}$ Mirjam Körner, Heike Ehrhardt, and Anne Steger, «Designing an interprofessional training program for shared decision making,» Journal of Interprofessional Care 27 (2013): 146-154.

49 Kristen Schaefer, and Susan Block, «Physician communication with families in the ICU: evidence-based strategies for improvement,» Current Opinion in Critical Care 15 (2009): 569-577.

${ }^{50}$ Noelle Junod et al., «Clinical supervisors' perceived needs for teaching communication skills in clinical practice,» Medical Teacher 31 (2009): e316-e322.

${ }^{51}$ María Bascuñan, «Cambios en la relación médico-paciente y nivel de satisfacción de los médicos,» Rev Méd Chile 133 (2005): 11-16.

${ }_{52}$ María Bascuñan, «Desarrollo de habilidades comunicacionales en medicina,» Pediatría al día $21, \mathrm{n}^{\circ} 5$ (2005b): 47-50.

${ }^{53}$ Nelson Herrera et al., «Representaciones sociales de la relación médico paciente en médicos y pacientes en Bogotá, Colombia,» Rev. salud pública 12, nº 3 (2010): 343-355. 
to encourage it during the early phases of the individual's development. In teenagers, the relationship between social skills and how their mothers raised them can be established.$^{54}$ Regarding autonomy and decision-making, the data obtained is similar to what has been reported herein; that the physician's cultural competency (ability to understand and adapt to the cultural, social and geographical context of the patient) is associated to a greater adherence and higher perception of the patient's autonomy in the decision making process. ${ }^{55,56,57}$

It is worth noting the lack of comments about communication with work teams, in contrast with other studies that highlighted the importance of good communication in specific health teams. For example, in the ER, the participation of other professionals and resources is frequently needed. In such teams is highly challenging to achieve effective communication, especially regarding confidentiality and accuracy in handing over shifts, frequent interruptions of the rhythm of work, the types of patients and diagnoses among others. ${ }^{58}$

Third, the study allowed the communication process in health to be conceived as a dialogue line where medical actions occur in a continuum in which many factors interact. The line is bi-directional and goes from clinical information obtained from the patient and from the clinical record to a true communication with a deep interaction between the doctor, the patient and the family. It is a mutual gain of trust, among strangers, through language, in order to obtain the expected therapeutic result and adherence to treatment. It follows a spiralling movement instead of lineal. It is necessary to start from the relation achieved, frequently repeat information and build on what has been mutually understood (Figure 1)

54 Judi Brownell, «Elwood Murray: Pioneering Methodologist in Communication,» Communication Education 63, $\mathrm{n}^{\circ} 4$ (2014): 329-343.

55 Pippa Hall et al., «Communication skills, cultural challenges and individual support: challenges of international medical graduates in a Canadian healthcare environment,» Medical Teacher 26 (2004): 120-125.

${ }^{56} \mathrm{~J}$ Rencic, A Liles, and Caridad Hernández, «The relationship between patient race and patients' perceptions of their physicians' Cultural Competence and Patient-Centered Communication Skills,» Journal of Investigative Medicine 53, $\mathrm{n}^{\circ} 1$ (2005): S24.

57 Amina Mahmud et al., «Health communication in primary health care - A case study of ICT development for health promotion,» BMC Medical Informatics and Decision Making, 2013: 13-17.

${ }^{58}$ Laura Mercer, «Patient perspectives on communication with the medical team: Pilot study using the communication assessment tool-team (CAT-T),» Patient Education and Counseling, 2008: 220-223. 
Figure 1

Dialogic line

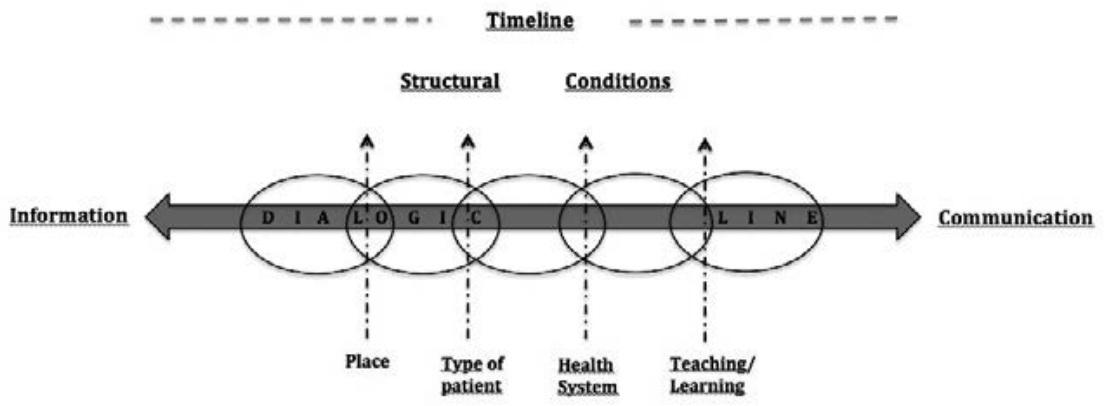

Figure 1

The dialogic line occurs in the temporal dimension. Information and communication are at the ends of the line. An increasing complexity of the process is assumed, which is affected by the structural conditions (place, type of patient and health system, among others), which are interrelated and subject to different kinds of tension.

Those conditions of making the medical action (process) possible were called structure. The process and the structure are closely linked. For example, in an emergency context, with critically ill patients, the dialogue line will tend to obtain important information (focused interview) instead of a communication where the mutual understanding of the health problem or a joint revision of the decision prevails.

Finally, regarding Communication and Medical Education and the possibility of attaining empathetic communication, the study highlights the need to design Medical School programmes that include developing skills allowing physicians to establish significant communication with the patient, the family and the health team. There are trustworthy and valid tests that provide guidelines for training and determine the standards for the professional practice. ${ }^{59}$

This study identified two specific key elements that must be present in any medical communication curriculum:

- Attentive listening

59 Daniel Duffy et al., «Assessing Competence in Communication and Interpersonal Skills: The Kalamazoo II Report,» Acad Med 79 (2004): 495-507. 
Attentive listening was identified as an important subcategory to achieve an effective communication. Our study supports the theory stating that physicians, as empathetic listeners, reinforce the healing process, increase adherence to the treatment and improve the patient's prognosis. ${ }^{60,61,62,63}$ In this respect, Jagosh, in 2011, described three types of advantages of developing this skill in physicians: (a) attentive listening as an important component to gather clinical data and diagnose; (b) attentive listening as healing and therapeutic agent; and (c) attentive listening as a means to boost and strengthen the physician-patient relationship. ${ }^{64}$

- Comprehensive training.

As described in the literature, many participants highlighted the importance of comprehensive training regarding significant communication with patients. Markakis demonstrated the importance of humanistic education in medical students as a way to achieve professional competency. ${ }^{65}$

\section{A new approach: $\mathrm{CCH}$. The three dimensions}

The attempt to achieve a more comprehensive category that responds to the complexity of the physician-patient relationship is not new. In 1956, Szasz and Hollender suggested that there are three social models of relationship. The first, called activity-passiveness is based on the dominant role, bearer of the knowledge, of the physician, in comparison with the complete submission of the patient. The second model, called guided cooperation, expects cooperation and acceptance of the patient of the decision made by the physician. The third model, of mutual participation,

${ }^{60}$ Melissa Wanzer, Melanie Booth-Butterfield, and Kelly Gruber, «Perceptions of health care providers' communication: relationships between patient-centered communication and satisfaction,» Health Commun 16 (2004): 363-384.

${ }^{61}$ Annette Davidsen, «Experiences of carrying out talking therapy in general practice: a qualitative interview study,» Patient Educ Couns 72 (2008): 268-275.

${ }^{62}$ Brian Haynes et al., «Interventions for enhancing medication adherence,» Cochrane Database Syst Rev 16, $\mathrm{n}^{\circ} 2$ (2008).

${ }^{63}$ Kelly Haskard and Robin DiMatteo, «Physician Communication and Patient Adherence to Treatment. A Meta-Analysis,» Med Care 47 (2009): 826-834.

${ }^{64}$ Justin Jagosh et al., «The importance of physician listening from the patients' perspective: Enhancing diagnosis, healing, and the doctor-patient relationship,» Patient Education and Counseling 85 (2011): 369-374.

${ }^{65}$ Kathryn Markakis et al., «The Path to Professionalism: Cultivating Humanistic Values and Attitudes in Residency Training,» Acad. Med 75 (2000): 141-150. 
implies an active role of the patient in the discussion and decision making process. ${ }^{66}$

Tatossian in turn, considered the inner world of the physician and the patient. He described a model that emphasises a direct relationship at an intellectual, affective (conscious or subconscious) level, but also in an imaginary world, the world of fantasy. The physician cannot focus only on the affected system (typical of a model focused on the organ) but on the patient as a whole, who is a compendium of sensations and feelings. ${ }^{67}$

This study acknowledges, in the confirmation of the medical act as a communicative act, the role of language as universal mediator of any human action, and acknowledges the argumentative power of the medical language in the purpose of healing the sick person, but also as means to show the truth, in a broader and flexible sense, fed by the patient's expectations, his/her family and surroundings.

The dialogue line described above assumes, during the initial clinical interview, a basic level of understanding the meanings of the statements uttered in the doctor's office, but this first step only reaches understanding level when this act allows acknowledging the other person, his/her differences and culture. Therefore, there is a hermeneutic level, which can be reached through dialogue and the need to reach possible and desirable agreements. It is in the ontological level of language where the physician and the patient argue and persuade each other.

To conclude $\mathrm{CCH}$ presupposes acknowledging the existence of three worlds (objective, subjective and social) and three validity expectations (truth, correctness and veracity), which are permanently relating in dynamic balance. These validity expectations are broken down in three scopes (Figure 2).

${ }^{66}$ Thomas Szasz and Marc Hollender, «A contribution to the philosophy of medicine; the basic models of the doctor-patient relationship,» A.M.A. Archives of Internal Medicine 97(5), 585-592. 1956.

http://ezproxy.utp.edu.co/docview/81844107?accountid=45809(last access: 2 de May de 2012).

67 Arthur Tatossian, The Phenomenology of Psychosis (Paris: Masson, 1979). 
Figure 2

Conceptual map of $\mathrm{CCH}$

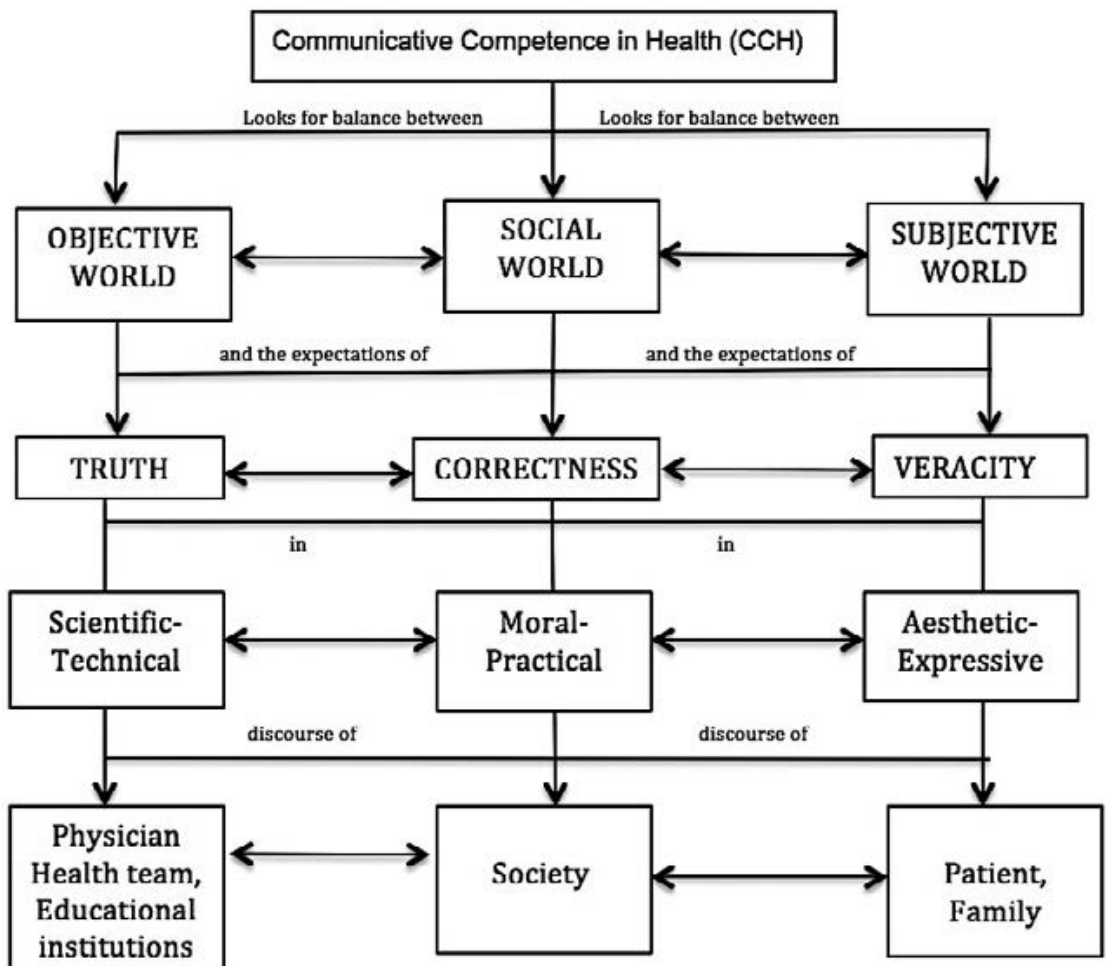

\section{1. Expectation of truth}

Expectation of truth refers to the objective world. For the physician, it is the permanent application of clinical judgement, a mixture of skills and knowledge throughout the clinical interview. The action is teleological within the objective world. Healing is the basis for the actions arising from the physician-patient relationship. This kind of argument is usually identified with the real world due to its force and possibility of verification (e.g. Medicine Based on Evidence). 


\section{2. Expectation of correctness}

Expectation of correctness is in the scope of the social world. It authenticates the actions and speeches, by appealing to normative speech. It is society who expresses itself through the values, aiming at justifying censorship or approving actions by means of reasons. The physician must, apart from the scientific objectivity, be able to interpret the social speeches about health and adapt them to his/her special context.

\subsection{Expectation of veracity (credibility)}

Expectation of veracity refers to the subjective world of communication, where authenticity or the lack of it in the speech depends on its agreement with actions. Physicians and patients live in this subjective world. The medical act begins with self-comprehension and recognition of the other as an autonomous being who is facing an obstacle for his/her life project.

This study provides valuable insights into factors that need to be taken into consideration when one considers the health communication process and the different circumstances in that physician-patient relationship occurs.

$\mathrm{CCH}$ is defined as the combination of necessary behaviour, knowledge and skills to acknowledge and balance these three worlds and their respective expectations of validity during the meeting with the patient, the family and the health team.

This study raises a number of questions that could be addressed through future research including development of methodology and courses to incorporate this new category in the health education programmes.

\section{Final thoughts and Recommendations}

This qualitative study describes the perception of a group of medical residents about the phenomenon of communication in health and delves into the understanding of the elusive concept of communication in health setting.

With respect to the physician-patient relationship, the majority of the focus group highlighted the importance of establishing a quick and trustworthy connection with the patient. Such connection can be achieved through empathetic listening: from the perspective of the patient, while taking into account the physician's and the patient's conditions and visions of the world. 
"Effective speaking" is only possible after "effective listening". Developing the capacity of paying attention and listening is as important (and it may be as difficult) as developing the ability to express ourselves.

Family is a key factor in the decision-making process. The physician's ability to establish a significant communication with the family will allow $\mathrm{him} /$ her to effectively make them part of the decision making process, as well as to properly handle the conflicts that may arise throughout the process.

The methodology used, based on the guidelines of grounded theory, allowed identification of three scopes within the medical setting (objective, social and subjective), and three types of validity expectation (truth, correction and veracity). The physician has to develop communication skills that allow him/her to reach a balance among those three worlds in order to achieve a significant communication with his/her patient aimed at reaching their main objective: healing and the prompt return to the patient's life project.

\section{Limitations}

The findings of the focus group discussion should be carefully interpreted in the light of the methodical limitations of the study. The selection bias leads to restrictions regarding the generalizability of the results. Similar studies with patients and employers are lacking, which might restrict us in generalizing the findings and discussing applicability of $\mathrm{CCH}$ in other contexts. Finally, since social influences appear to play such an important role in the development of $\mathrm{CCH}$, an ethnographic approach could have complemented the category with valuable insights.

\section{Bibliography}

Anderson, Elizabeth, Jenny Ford, and Thorpe Lucy. «Learning to listen: Improving students' communication with disabled people.» Medical Teacher 33, $\mathrm{n}^{\circ} 1$ (2011): 44-52.

Aspegren, Knut. «BEME Guide No. 2: Teaching and learning communication skills in medicine - A review with quality grading of articles.» Medical Teacher 21 (1999): 563-570.

Association of American Medical Colleges. «Report 3. Contemporary issues in medicine: Communication in medicine.» Washington, DC., 1999.

Bascuñan, María. «Cambios en la relación médico-paciente y nivel de satisfacción de los médicos.» Rev Méd Chile 133 (2005): 11-16. 
. «Desarrollo de habilidades comunicacionales en medicina.» Pediatría al día 21, n 5 (2005b): 47-50.

Bate, Paul, Peter Mendel and Robert Glenn. Organising for quality: The improvement journey of leading hospitals in Europe and the United States. Oxford: The Nuffield Trust, Radcliffe Publishing. , 2008.

Bombeke, Katrien, Linda Symons, Etienne Vermeire, Luc Debaene, Sandrina Schol, et al. «Patient-centredness from education to practice: The 'lived' impact of communication skills training.» Medical Teacher 34 (2012): e338-e348.

Brownell, Judi. «Elwood Murray: Pioneering Methodologist in Communication.» Communication Education 63, $\mathrm{n}^{\circ} 4$ (2014): 329-343.

Butani, Lavjay, Debora Paterniti, Daniel Tancredi and Su Ting. «Attributes of residents as teachers and role models - A mixed methods study of stakeholders.» Medical Teacher. 35 (2013): e1052-e1059.

Cook, David, Georges Bordage and Henk Schmidt. «Description, justification and clarification: a framework for classifying the purposes of research in medical education.» Med Educ 42 (2008): 128-133.

Davidsen, Annette. «Experiences of carrying out talking therapy in general practice: a qualitative interview study.» Patient Educ Couns 72 (2008): 268-275.

De Haes, Hanneke, and Jozien Bensing. «Endpoints in medical communication research, proposing a framework of functions and outcomes.» Patient Educ Couns. 74 (2009): 287-94.

Des Jarlais, Don, Cynthia Lyles, and Nicole Crepaz. «Improving the reporting Quality of Nonrandomized Evaluations of Behavioral and Public Health Interventions: The Trend Statement.» American Journal of Public Health 94 (2004): 361-366.

Duffy, Daniel, Geoffrey Gordon, Gerald Whelan, Kathy Cole-Kelly, Richard Frankel, et al. «Assessing Competence in Communication and Interpersonal Skills: The Kalamazoo II Report.» Acad Med 79 (2004): 495-507.

Flaherty, Joseph. «Education and evaluation of interpersonal skills.» En The interpersonal dimension in medical education., de Agnes Rezler y Joseph. Flaherty, 101-146. New York: Springer Verlag, 1985.

Glaser, Barney. Basics of Grounded Theory Analysis: Emergence Vs. Forcing Sociology Press, USA., 1992.

Hall, Pippa, Erin Keely, Suzan Dojeiji, Anna Byszewski, and Meredith Marks. «Communication skills, cultural challenges and individual support: challenges of international medical graduates in a Canadian healthcare environment.» Medical Teacher 26 (2004): 120-125.

Haskard, Kelly, and Robin DiMatteo. «Physician Communication and Patient Adherence to Treatment. A Meta-Analysis.» Med Care 47 (2009): 826-834.

Hastings, Adrian, Robert McKinley, and Robin Fraser. «Strengths and weaknesses in the consultation skills of senior medical students: Identification, enhancement and curricular change.» Med Educ 40, nº 5 (2006): 437-443. 
Haynes, Brian, Elizabeth Ackloo, Navdeep Sahota, Heather McDonald, and Xiaomei Yao. «Interventions for enhancing medication adherence.» Cochrane Database Syst Rev 16, n 2 (2008).

Herrera, Nelson, María Gutiérrez, Magnolia Ballesteros, Romina Izzedin, and Angela Gómez. «Representaciones sociales de la relación médico paciente en médicos y pacientes en Bogotá, Colombia.» Rev. salud pública 12, nº 3 (2010): 343-355.

Jagosh, Justin, Joseph Boudreau, Yvonne Steinert, Mary MacDonald, and Lois Ingram. «The importance of physician listening from the patients' perspective: Enhancing diagnosis, healing, and the doctor-patient relationship.» Patient Education and Counseling 85 (2011): 369-374.

Junod, Noelle, Johanna Sommer, Patricia Hudelson, Florence Demaurex, et al. «Clinical supervisors' perceived needs for teaching communication skills in clinical practice.» Medical Teacher 31 (2009): e316-e322.

Körner, Mirjam, Heike Ehrhardt, and Anne Steger. «Designing an interprofessional training program for shared decision making.» Journal of Interprofessional Care 27 (2013): 146-154.

Kinnersley, Paul, and John. Spencer. «Communication skills teaching comes of age.» Med Educ 42 (2008): 1052-1053.

Kurtz, Suzanne, Jonathan Silverman, John Benson, and Juliet Draper. «Marrying content and process in clinical method teaching: Enhancing the CalgaryCambridge guides.» Acad Med 78 (2003): 802-809.

Mahmud, Amina, Ewy Olander, Sara Eriksén, and Bo Haglund. «Health communication in primary health care - A case study of ICT development for health promotion.» BMC Medical Informatics and Decision Making, 2013: 13-17.

Markakis, Kathryn, Howard Beckman, Anthony Suchman, and Richard Frankel. «The Path to Professionalism: Cultivating Humanistic Values and Attitudes in Residency Training.» Acad. Med 75 (2000): 141-150.

Mercer, Laura. «Patient perspectives on communication with the medical team: Pilot study using the communication assessment tool-team (CAT-T).» Patient Education and Counseling, 2008: 220-223.

Rees, Charlotte, and Paul Garrud. «Identifying undergraduate medical students' attitudes towards communication skills learning: a pilot study.» Medical Teacher 23, no 4 (2001): 400-406.

Rencic, J, A Liles, and Caridad Hernández. «The relationship between patient race and patients' perceptions of their physicians' Cultural Competence and PatientCentered Communication Skills.» Journal of Investigative Medicine 53, $\mathrm{n}^{\circ} 1$ (2005): S24.

Schaefer, Kristen, and Susan Block. «Physician communication with families in the ICU: evidence-based strategies for improvement .»Current Opinion in Critical Care 15 (2009): 569-577.

Silverman, Jonathan, Suzanne Kurtz, and Juliet Draper. Skills for communicating with patients. First Edition 1998. 2nd ed. New York: Radcliffe Publishing Ltd. , 2013. 
Strauss, Anselm, and Juliet Corbin. Basics of Qualitative Research: Techniques and Procedures for Developing Grounded Theory. Sage Publications, USA. , 2008.

Szasz, Thomas, and Marc Hollender. A contribution to the philosophy of medicine; the basic models of the doctor-patient relationship. A.M.A. Archives of Internal Medicine, 97(5), 585-592. 1956. http://ezproxy.utp.edu.co/docview/81844107?a ccountid=45809(last access: 2 de May de 2012).

Tatossian, Arthur. The Phenomenology of Psychosis. Paris: Masson, 1979.

Universities UK. «Statement of guiding principles relating to the commissioning and provision of communication skills in preregistration and undergraduate education for healthcare professionals Universities UK.» United Kingdom, 2003.

Wanzer, Melissa, Melanie Booth-Butterfield, and Kelly Gruber. «Perceptions of health care providers' communication: relationships between patient-centered communication and satisfaction.» Health Commun 16 (2004): 363-384.

Watmough, Simon, Anne Garden, and David Taylor. «Does a new integrated PBL curriculum with specific communication skills classes produce Pre Registration House Officers (PRHOs) with improved communication skills?» Medical Teacher, 28, no 3 (2006): 264-269.

Wittenberg-Lyles, Elayne, Joy Goldsmith, and George Demiris. «The Impact of Family Communication Patterns on Hospice Family Caregivers.» Journal of Hospice and Palliative Nursing 14, $\mathrm{n}^{\circ} 1$ (2012).

\section{Copyright}

Copyright for this article is retained by the Publisher. It is an Open Access material that is free for download, distribution, and or reuse in any medium only for non-commercial purposes; provided any applicable legislation is respected, the original work is properly cited, and any changes to the original are clearly indicated. 